\title{
Capital Punishment and Lay Participation
}

\begin{abstract}
This chapter examines two new forms of lay participation in Japanese capital justice. The lay judge reform of 2009 has stimulated many changes in formal rules and standard operating procedures in Japan's criminal process. These changes may be shifting the balance of power in Japanese criminal justice- a balance that has long favored law enforcement interests. Yet before and after the lay judge reform there are striking continuities in criminal justice outcomes, in conviction rates, punishment patterns, and death sentencing. The second reform is a victim participation system, which moves victims and survivors closer to center stage of Japan's criminal process, and which reflects and reinforces a culture of vengeance. Together, these two forms of lay participation may be doing as much to entrench capital punishment in Japan as to challenge and change it.
\end{abstract}

Keywords Lay judge system - Victim participation system - Burden • Closure $\cdot$ Culture of vengeance

One of the most striking facts about the death penalty in Japan is the dearth of significant change. The contrasts with America are stark. In the United States, public support for the death penalty has fallen to its lowest levels since the 1960s. Death sentences and executions have declined by about 80 percent since the 1990s. Nine states have abolished the

(C) The Author(s) 2020

D. T. Johnson, The Culture of Capital Punishment in Japan, Palgrave Advances in Criminology and Criminal Justice in Asia, https://doi.org/10.1007/978-3-030-32086-7_5 
death penalty since 2007 (making a total of 21), and in 4 other states governors have declared a moratorium on executions. Executions in several other states have been stopped because of botched executions and problems obtaining the chemicals used in lethal injection. The U.S. Supreme Court has prohibited execution of the mentally disabled and of juveniles. And of the more than 8000 death sentences imposed in the United States between 1973 and 2013, only 16 percent-about 1 in 6resulted in execution. Most of the rest were overturned on appeal, commuted, or exonerated. So much change has occurred that some analysts believe the death penalty in America is "at the end of its rope" and that it will be abolished "not in a matter of generations, but in a matter of years." l

In Japan one sees far more continuity in death penalty policy and practice. Public support for capital punishment remains around 80 percent. Death sentences and executions continue to occur on a regular basis. There has been no extended moratorium on executions since a 40-month one ended in 1993-more than a quarter-century ago. ${ }^{2}$ Japan's Supreme Court has done little to develop a meaningful jurisprudence of capital punishment. Most people sentenced to death get executed. And few serious observers believe abolition is near.

The previous three chapters explained why there has been so little death penalty change in Japan. When death is not deemed a different form of punishment, appellate courts seldom find reason to reverse death sentences, and the public remains convinced that capital punishment is a righteous response to heinous crime (Chapter 2). When the state kills in secret, nobody knows when executions are botched, and the public remains confident that the state kills decently (Chapter 3 ). And when a culture of denial results in the revelation of few wrongful convictions, most people remain untroubled by the possibility of error in life-anddeath decision-making, and most leaders do little to address problems in the system (Chapter 4). This chapter explores the possibilities for change in Japanese capital punishment that could come from two reforms that took effect in 2009: a lay judge system that gives citizens a direct voice

\footnotetext{
${ }^{1}$ Brandon L. Garrett, End of Its Rope: How Killing the Death Penalty Can Revive Criminal Justice (Harvard University Press, 2017), p. 1.

${ }^{2}$ Mika Obara-Minnitt, Japanese Moratorium on the Death Penalty (Palgrave Macmillan, 2016).
} 
in death penalty decision-making, and a victim participation system that moves crime victims and survivors closer to center stage of the criminal process. Since both reforms are relatively recent, it will take more time to discern their full effects. So far, however, they seem to be doing more to entrench capital punishment in Japan than to change or challenge it. ${ }^{3}$

\section{A Stone Into the Pond?}

In 2009, Japan began a new trial system in which six lay persons sit with three professional judges to adjudicate guilt and determine sentence for murder and some other serious offenses. ${ }^{4}$ The lay judge system puts citizen participation at the center of Japanese criminal trials (and death penalty decision-making) for the first time since 1943, when Japan's original Jury Act was suspended after fifteen years of fitful use (fewer than 500 jury trials were held in the 15 years before suspension). ${ }^{5}$ Some analysts believe this trial reform will remake the country's criminal justice system. As they see it, the lay judge system has thrown "a stone into the pond" of criminal justice, and the ripples are gradually spreading. 6

Several changes in the criminal process have been stimulated by the lay judge reform. ${ }^{7}$ Since citizens cannot be asked to serve in court for long periods of time, a pretrial process was created to narrow and define the issues to be contested at trial. This has led to some improvement in the amount of evidence that prosecutors disclose to the defense before a trial begins, though more disclosure is needed. There also has been

${ }^{3}$ David T. Johnson, “Capital Punishment Without Capital Trials in Japan's Lay Judge System”, The Asia-Pacific Journal/Japan Focus, Vol. 7 (2009), pp. 1-40.

${ }^{4}$ David T. Johnson, “Japan's Lay Judge System”, in Jacqueline E. Ross and Stephen C. Thaman, editors, Comparative Criminal Procedure (Elgar, 2016), pp. 396-421.

${ }^{5}$ Dimitri Vanoverbeke, Juries in the Japanese Legal System: The Coming Struggle for Citizen Participation and Democracy (Routledge, 2015).

${ }^{6}$ See, for example, Shinomiya Satoru, "Defying Experts' Predictions, Identifying Themselves as Sovereign: Citizens' Responses to Their Service as Lay Judges in Japan", Social Science Japan, No. 43 (September 2010), pp. 8-13.

${ }^{7}$ For impact studies of the lay judge reform in Japan, see Erik Herber, Lay and Expert Contributions to Japanese Criminal Justice (Routledge, 2019, especially Chapter 6 on "Lay Judges and Sentencing"); and Rieko Kage, Who Judges? Designing Jury Systems in Japan, East Asia, and Europe (Cambridge University Press, 2017, especially Chapter 9 on "The Impact of New Lay Judge Systems"). 
progress toward recording interrogations, though more should be done here too. Bail has become easier to obtain as judges recognize the dangers of "kidnap justice" (hitojichi shiho), whereby pretrial detention is ruled necessary for most defendants who do not confess. Trials are easier to understand and more interesting than they used to be, for they are less reliant on the written statements (chosho) that are composed by police and prosecutors behind the closed doors of an interrogation room. Access to defense lawyers has improved, especially in the critical pretrial period when investigators focus on making suspects confess. One result is that suspects have become less cooperative, as more than 80 percent of prosecutors affirmed in a 2011 survey. Bar associations are training defense lawyers to become more effective advocates at trial. And so on. ${ }^{8}$ These changes in procedure could transform death penalty decision-making by making citizens more aware of the reality of capital punishment. As U.S. Supreme Court Justice Thurgood Marshall posited in 1972, many people support capital punishment partly because they are ignorant about it. On this so-called "Marshall hypothesis", when people learn more about capital punishment, they come to regard it as immoral and unnecessary. But this kind of learning takes time. If the lay judge reform is going to transform capital punishment, it will be by evolution, not revolution. ${ }^{9}$

Deep change in Japanese capital punishment is hardly guaranteed. For one thing, civilian participation could be marginalized by legal professionals-prosecutors and judges especially-who aim to maintain their standard operating procedures. Indeed, marginalization into obscurity has happened several times in the past when reforms tried to make citizen participation a more central part of Japan's criminal process. The most striking examples are the prewar jury system and the postwar Prosecution Review Commissions, both of which had little effect on the actual practice of criminal justice. ${ }^{10}$

\footnotetext{
${ }^{8}$ Shinomiya Satoru, "Kokumin no Shutai teki - Jisshitsu teki Sanka wa Jitsugen Shite Iru ka: Saibanin Seido Shikko 10nen to Kongo no Kadai", Jiyu to Seigi, Vol. 70, No. 5 (May 2019), pp. 8-17.

${ }^{9}$ David T. Johnson and Setsuo Miyazawa, "Japanese Court Reform on Trial”, in Rosann Greenspan, Hadar Aviram, and Jonathan Simon, editors, The Legal Process and the Promise of Justice: Studies Inspired by the Work of Malcolm Feeley (Cambridge University Press, 2019), pp. 122-138.

${ }^{10}$ Kent Anderson and Mark Nolan, "Lay Participation in the Japanese Justice System: A Few Preliminary Thoughts Regarding the Lay Assessor System (saiban-in seido) from
} 
There are three signs that lay judges may be getting marginalized in the new trial system too. First, Japan's high conviction rate has not significantly declined. In comparable cases, the conviction rate went from 99.4 percent in 2006-2008 to 99.1 percent in 2009-2018. ${ }^{11}$ Second, sentencing patterns have changed for only a few offenses (sex crimes especially), and even then just a little. ${ }^{12}$ Third, when prosecutors seek a sentence of death, lay judge panels are actually more likely to impose the ultimate punishment than panels of three professional judges were in the old trial system. From 2010 to 2018 , Japanese prosecutors sought a sentence of death for 53 defendants, and a death sentence was imposed on 36 of them (68 percent). By comparison, in the three decades that preceded the lay judge reform (1980-2009), prosecutors sought a sentence of death for 346 defendants, and a death sentence was imposed on 193 of them (56 percent). ${ }^{13}$ Some of these signs of stasis in criminal justice outcomes result from adaptations to the lay judge system made by prosecutors and judges. Most notably, prosecutors have become more cautious about charging cases and seeking severe sentences, in order to avoid undesirable outcomes in a trial system that is unfamiliar and unpredictable. ${ }^{14}$ The judiciary has been conservative too, especially in its

Domestic, Historical, and International Psychological Perspectives", Vanderbilt Journal of Transnational Law, Vol. 37 (2004), pp. 935-992.

${ }^{11}$ Takeda Masahiro, "Utagawashiki wa Muzai Tettei”, Fukui Shimbun, March 10, 2019, p. 19.

${ }^{12}$ Stacey Steele, Carol Lawson, Mari Hirayama, and David T. Johnson, "Lay Participation in Japanese Criminal Justice: Prosecution Review Commissions, the Lay Judge System, and Penal Institution Visiting Committees", Asian Journal of Law \& Society (forthcoming, 2020).

${ }^{13}$ Note, too, that the increased probability of a death sentence being imposed if prosecutors seek one partly reflects the fact that prosecutors have become more selective about seeking a sentence of death in the lay judge system. In the pre-reform period (1980-2009), prosecutors sought a sentence of death an average of 11.5 times per year. For the lay judge system (2010-2018), the comparable figure is 5.9. This decline in the number of death sentences sought not only reflects an increase in prosecutorial caution; it also reflects a decline in Japan's homicide rate. The increased propensity to impose a sentence of death when prosecutors seek one is especially noticeable in homicide cases with 3 or more victims. See Takeda Masahiro, "Genbatsuka no Ippo de Yuyo Oku", Kyoto Shimbun, March 23,2019 , p. 6.

${ }^{14}$ Takeda Masahiro, "Saibanin Seido Kaishi kara 5nen: Kensatsu wa Taisho Jiken o Shincho ni Kiso: Saibanin Kohosha no Jitairitsu, 60\% Koeru", Journalism, September 
reliance on benchmarks that are based on sentencing patterns from the pre-lay judge period. ${ }^{15}$

In sum, Japan's lay judge reform has stimulated change in formal rules and standard operating procedures in many parts of the criminal process, and the net effect could be a shift in the balance of power in Japanese criminal justice-a balance that long has favored law enforcement's interest in obtaining confessions, convictions, and capital sentences. ${ }^{16}$ The lay judge reform has also stimulated more public interest and trust in Japanese criminal justice. ${ }^{17}$ In these senses, the results of Japan's lay judge reform do seem "quite remarkable."18 Yet there are also striking continuities in Japanese criminal justice, in conviction rates, in punishment patterns, and in death sentencing. Together they suggest that the changes in Japanese criminal procedure may be mostly incidental music. If the proof is in the pudding, then it needs to be acknowledged that Japan's lay judge system has not changed much that matters in criminal justice outcomes generally, or in capital punishment outcomes specifically-so far. ${ }^{19}$ But the ripples of reform are continuing to spread. As the next section suggests, the future effects of the new trial system will depend on how judges and defense lawyers respond to prosecutors' efforts to maintain their control over case outcomes. ${ }^{20}$

2014, pp. 136-143; and Takeda Masahiro, “Zaimei-Ochi’ Hinpatsu Kisoritsu Teika”, Kochi Shimbun, January 30, 2019, p. 12.

${ }^{15}$ Masahito Saeki and Eiichiro Watamura, "The Impact of Previous Sentencing Trends on Lay Judges' Sentencing Decisions," in Jianhong Liu and Setsuo Miyazawa, editors, Crime and Justice in Contemporary Japan (Springer, 2018), pp. 275-290.

${ }^{16}$ Malcolm M. Feeley and Setsuo Miyazawa, editors, The Japanese Adversary System in Context: Controversies and Comparisons (Palgrave Macmillan, 2002).

${ }^{17}$ See, for example, Masahiro Fujita, Japanese Society and Lay Participation in Criminal Justice: Social Attitudes, Trust, and Mass Media (Springer, 2018); and Ii Takayuki and Saibanin Raunji, editors, Anata mo Ashita wa Saibanin!? (Nihonhyoronsha, 2019).

${ }^{18}$ Daniel H. Foote, "Citizen Participation: Appraising the Saiban'in System”, Michigan State International Law Review, Vol. 22, No. 3 (2014), p. 8.

${ }^{19}$ David T. Johnson, "Japan's Lay Judge System”, in Jacqueline E. Ross and Stephen C. Thaman, editors, Comparative Criminal Procedure (Elgar, 2016), pp. 396-421.

${ }^{20}$ Takano Takashi, "Saibanin Seido no Koka: 10nen o Furikaette", Jiyu to Seigi, Vol. 70, No. 5 (May 2019), pp. 18-29. 


\section{Dogs That Do Not Bark}

In Arthur Conan Doyle's "Silver Blaze" story (1892), detective Sherlock Holmes notices that a dog did not bark during the theft of a horse. From this, he induced that the thief was not a stranger, which reduced the number of suspects to one. Case closed.

Inspector Gregory of Scotland Yard: You consider this to be important? Sherlock Holmes: Exceedingly so.

Inspector Gregory: Is there any point to which you would wish to draw my attention?

Sherlock Holmes: To the curious incident of the dog in the night-time.

Inspector Gregory: The dog did nothing in the night-time.

Sherlock Holmes: That was the curious incident.

The most curious thing about criminal justice reform in Japan is how much pressure for change has been directed at prosecutors-and how little has been directed at judges and defense lawyers. To be sure, prosecution does need reform. When more than one-quarter of prosecutors acknowledge that they have been directed by a superior to create a dossier (chosho) that differs from what a suspect or witness actually told them, the imperative of change is obvious. ${ }^{21}$ It is also obvious that prosecutors and their allies will resist reform, for power seldom cedes control voluntarily. ${ }^{22}$ But prosecutors are only one part of a "criminal court community" that is also inhabited by judges and defense lawyers. If prosecutors dominate this community, it is partly because judges and defense lawyers have let them. Much talk about reform overlooks the crucial fact that judges and defense lawyers have frequently failed to perform their duty to check prosecutors' power in the criminal process. ${ }^{23}$

Consider judges, who have the final word in the criminal process. They routinely use their authority to give prosecutors (and police) what they want: arrest warrants, detention warrants, evidence admitted at trial,

${ }^{21}$ Asahi Shimbun, "Kenji 26\% 'Shiji Sareta Keiken': Jissai no Kyojutsu to Kotonaru Chosho no Sakusei," March 11, 2011, p. 38.

${ }^{22}$ Suo Masayuki, Sore demo Boku wa Kaigi de Tatakau: Dokyumento Keiji Shiho Kaikaku (Iwanami Shoten, 2015).

${ }^{23}$ David T. Johnson, The Japanese Way of Justice: Prosecuting Crime in Japan (Oxford University Press, 2002), pp. 61-85. 
convictions, and sentences. And when prosecutors do not get what they want from lower courts, they frequently get it on appeal. There is nothing necessary or inevitable about this judicial tendency. Postwar reforms included many progressive provisions, from the right to due process and a fair trial to protection against self-incrimination. But in translating the "law on the books" into the "law in action," Japan's judiciary has "adopted, accepted, or silently acquiesced in a wide range of interpretations that greatly circumscribed the protections for suspects and defendants, while granting broad authority to investigators." 24 This extraordinary deference of judges to prosecutors is why some defense lawyers say that if they could change only one thing about Japanese criminal justice, it would be the tendency of judges to yield to prosecutors in their decision-making. On this view, judges defer to prosecutors so routinely that reforming the judiciary is even more urgent than reforming the procuracy. As one defense lawyer put it, "if judges change, prosecutors will have to change too." 25

Like judges, defense lawyers have also been passive toward prosecutors and police. Legally and ethically, their obligation is to try, by every fair and legal means, to get the best result for their clients, but this duty often goes unfulfilled. For decades, many defense lawyers have been little more than passive props in trial ceremonies that are scripted by prosecutors, certified by judges, and barely contested by the defense. There are many reasons for this passivity, including some over which defense lawyers have little control. Judicial interpretations of law have restricted what defense attorneys can do for criminal suspects and defendants. Moreover, all but a few criminal cases pay poorly in comparison to the other work opportunities that Japanese attorneys have (in criminal defense as in other areas of life, you often get what you pay for). But while law and economics are impediments to good defense lawyering in Japan, the cultural obstacles may be even more formidable. In my view, defense lawyers are complicit in a state of affairs that Hirano Ryuichi (former president of Tokyo University and the dean of criminal justice studies in Japan) described as "abnormal," "diseased," and "really quite

${ }^{24}$ Daniel H. Foote, "Policymaking by the Japanese Judiciary in the Criminal Justice Field," Hoshakaigaku, No. 72 (2010), p. 18.

${ }^{25}$ David T. Johnson, "War in a Season of Slow Revolution: Defense Lawyers and Lay Judges in Japanese Criminal Justice", The Asia-Pacific Journal/Japan Focus, Vol. 9 (June $29,2011)$, pp. 1-11. 
hopeless." 26 Traditionally, defense lawyers in Japan have seldom advised suspects or defendants to invoke their right to silence. In 1991, a survey of more than 1000 lawyers found that over 60 percent had never recommended that a suspect or defendant exercise the right to remain silent. Not a single time. The same survey found that two-thirds of lawyers had never asked that a witness testifies in court when prosecutors sought to use written statements instead of live testimony, and three-quarters had never asked a court to compel prosecutors to disclose evidence. This level of passive acquiescence is like doing sumo with one hand tied behind your back.

Since it is often in a suspect's best interest not to talk to interrogators, it is puzzling why there is so much reluctance to recommend this fundamental right. One cause is the difficulty of maintaining silence through Japan's long interrogation process. As one attorney told me, "if I advise 100 suspects to remain silent, only one or two would be capable of staying mute until the [long] interrogations end." 27 Still, in many criminal cases the best thing a defendant in Japan can do is what a full-page ad in the Boston Yellow Pages once urged (under "Attorneys"): JUST SHUT UP.

Even in trials where defendants claim innocence, it is striking how little vigorous advocacy there can be. During a rape trial in which the defendant insisted that the victim had consented to sex, I watched one defense lawyer scold his client in open court. "Who are you trying to kid?" he asked his befuddled client. "Do you really think anyone is going to believe your story? I don't." And in a murder trial in which prosecutors sought a sentence of death for a defendant who had a prior conviction for homicide, a pair of defense lawyers passed up numerous opportunities to press the prosecution's key witnesses about weaknesses in their testimony. When prosecutors in this trial persistently pressed the defendant with incriminating questions despite the defendant's complete silence, his lawyers barely uttered a word of protest. I was not surprised when that defendant was condemned to death. And I suppose he may have wondered about his own legal representation: with friends like this, who needs enemies?

\footnotetext{
${ }^{26}$ Hirano Ryuichi, "Diagnosis of the Current Code of Criminal Procedure", Law in Japan, Vol. 22 (1989), pp. 129-142.

${ }^{27}$ David T. Johnson, "War in a Season of Slow Revolution: Defense Lawyers and Lay Judges in Japanese Criminal Justice", The Asia-Pacific Journal/Japan Focus, Vol. 9 (June 29, 2011), pp. 1-11.
} 
It is difficult to defend homicide cases in a country where the criminal process is significantly tilted toward state interests. It also needs to be acknowledged that there is not one right way to do criminal defense. Culture counts, and in Japan's legal culture, repentance and confession are salient themes. ${ }^{28}$ Criminal defense strategy should depend on the case and the context - and Japan is not the United States. But sometimes the best defense is a good offense, even in Japan.

Defending someone accused of murder is not a job for people seeking approval. It is a job for those who are willing to rattle cages, make enemies, and raise a little hell. By raising hell, defense lawyers honor the law. ${ }^{29}$ The need to "rattle cages" is what defense lawyer Takano Takashi had in mind when he told me that the lay judge system gives Japanese defense lawyers a precious opportunity to improve a system that sorely needs change:

The advent of the lay judge system [in 2009] marks the beginning of a war against professional judges. Many professional judges want to minimize the scope and significance of the lay judge reform. But this is a power struggle. [If we are to fulfill our obligation to protect the rights of defendants,] we defense lawyers must empower lay judges to stand up to professional judges and defeat them in the deliberation room. For this to happen, defense lawyers must shed the feeling of uselessness that has been their big burden. Defense lawyers are habituated to being passive in the criminal process. We have been socialized to believe that what we do does not matter. But with lay judges in front of us, we are no longer talking to a wall. Now we have a real opportunity to make a difference, and we need to make the most of it. We must fight in open court to change a system that is stacked against us. ${ }^{30}$

Time will tell what Japanese defense lawyers make of the new opportunities the lay judge reform is giving them. By most accounts, defense lawyering has improved since the reform took effect in 2009. At the same time, lay judges routinely report that they found the trial

${ }^{28}$ Daniel H. Foote, "The Benevolent Paternalism of Japanese Criminal Justice", California Law Review, Vol. 80, No. 2 (1992), pp. 317-390.

${ }^{29}$ Alan Dershowitz, The Best Defense (Vintage, 1983).

${ }^{30}$ David T. Johnson, "War in a Season of Slow Revolution: Defense Lawyers and Lay Judges in Japanese Criminal Justice", The Asia-Pacific Journal/Japan Focus, Vol. 9 (June $29,2011)$, pp. 1-11. 
presentations made by prosecutors clearer and more persuasive than those made by defense lawyers. ${ }^{31}$ And continued change for the better in Japanese defense lawyering is far from guaranteed, not least because of new challenges raised by the other major reform in civilian participation in Japan's criminal process.

\section{Victims And the Myth of Closure}

The second major reform in Japanese criminal justice is the creation of a victim participation system that moves victims and survivors close to center stage of the criminal process. One question is whether the increased salience of victims in Japanese capital punishment constitutes progress or regress. The answer depends on whether one regards capital punishment as a victim-service program. ${ }^{32}$

Victims have long been neglected and ignored in Japan's criminal process, and they certainly deserve more support and consideration than they have historically received. But while efforts to help them are necessary, Japan's victims' rights movement has been, for the most part, harshly punitive. Other models for thinking about how victims might be helped have been neglected and ignored, including some that are more "restorative" in the sense that they focus on healing the harms caused by crime rather than encouraging the venting of vengeful feelings. ${ }^{33}$

In Japan's punitive approach to victims' rights, victims and their families have taken on an almost sacred status in the criminal process, and this makes it difficult to cross-examine them or otherwise challenge their assertions. ${ }^{34}$ Since vigorous cross-examination is an indispensable tool for determining truth at trial, the difficulty of using it with victims and survivors is worrisome. In a murder trial in Tokyo, for example, the victim's

${ }^{31}$ Erik Herber, Lay and Expert Contributions to Japanese Criminal Justice (Routledge, 2019), p. 172.

${ }^{32}$ David T. Johnson, "Killing Asahara: What Japan Can Learn About Victims and Capital Punishment from the Execution of an American Terrorist", The Asia-Pacific Journal/Japan Focus, Vol. 10 (September 9, 2012), pp. 1-15.

${ }^{33}$ Danielle Sered, Until We Reckon: Violence, Mass Incarceration, and a Road to Repair (The New Press, 2019).

${ }^{34}$ Maiko Tagusari, "Does the Death Penalty Serve Victims?"; and David T. Johnson, "Does Capital Punishment Bring Closure to Victims?", in Ivan Simonovic, editor, Death Penalty and the Victims (United Nations, 2016), pp. 41-48 and pp. 75-82. 
mother testified that she missed her deceased daughter greatly even though (the defense lawyer knew) the mother and daughter had been on bad terms for years before the daughter was killed, and even though the mother collected a tidy life insurance sum after the loss of her daughter. The defense lawyer told me that he remained silent about this issue out of fear of being criticized for "re-victimizing" the mother. When victims are seen as sacred, some truths are hard to utter.

Many supporters of capital punishment believe death sentences and executions give victims "closure"-a satisfying feeling that something terrible has ended. But closure of this kind is a myth, for survivors are never "over and done with" their loss. The unfortunate truth is that their suffering does not end. A better conception of closure would see it as a process of "memory work" through which survivors construct meaningful narratives about a killing and how they have dealt with it. In this sense, the quest for closure continues for as long as the survivor is alive, and recognizing the myth of closure reminds survivors that they should not hope for a finality that is illusory. The promise of closure as an ending is a false comfort that is doomed to disappoint. ${ }^{35}$

Capital punishment seldom provides closure for persons bereaved by homicide, but it does create resentment among those whose cases are not deemed capital. In Japan, prosecutors seek a sentence of death in only about 1 out of every 100-200 murder cases. When the severity of a sentence is regarded as a measure of how much a victim is valued-and when a death sentence is seen as a token of society's esteem for a victim-the non-capital sentences that most defendants receive foster the perception among survivors that the victim they have lost is undervalued. ${ }^{36}$ To dispel this perception, prosecutors would need to seek capital sanctions as frequently as they were used in the Tokugawa era. Even the most ardent supporters of Japanese capital punishment do not want to go back to that future.

While closure is mostly a myth, it is a myth that performs important functions in the age of abolition. For one thing, closure paints over the disturbing reality of execution with a positive patina that people can endorse, for it is easier to say (and to be seen as saying) "I support

${ }^{35}$ Jody Lynee Madeira, Killing McVeigh: The Death Penalty and the Myth of Closure (New York University Press, 2012).

${ }^{36}$ Scott Turow, Ultimate Punishment: A Lawyer's Reflections on Dealing with the Death Penalty (Farrar, Straus and Giroux, 2003), pp. 47-56. 
victims" than "I want vengeance." For another, when closure is a central purpose of capital punishment, people do not need to worry about whether execution is an excessive use of power by government, because the closure frame "de-governmentalizes" the death penalty by depicting the state as the servant of society rather than its master. The language of "closure" also connects capital punishment to the history of community control over punishment. In the United States, claims about closure are linked to bloody traditions of lynching and vigilantism. In Japan, the language of closure is connected to a rhetoric of "repentance" and "atonement" that has been salient for centuries. The essence of this rhetoric is: "I want the offender to repent and atone; I want him dead." It is no coincidence that the rise of closure and its cognates corresponded with death penalty increases in Japan after 2000 and with death penalty increases in the United States a decade earlier. When the death penalty is framed as a matter of serving victims and helping them achieve closure, the ultimate effect is the legitimation of a sanction that has become increasingly difficult to justify on other grounds. ${ }^{37}$

\section{Victims and the Culture of Vengeance}

Murder trials in Japan are emotionally intense. Tears are everywhere. Survivors cry when they testify and while observing the proceedings. Spectators and reporters weep. Prosecutors cry when they describe the suffering of the survivors. Defense lawyers cry while listening to the statements of the bereaved. Defendants cry-and when they are not crying they slump over in postures of anguish and shame. And the defendant's parents and relatives often cry while reading their statements to the court. One mother of a defendant asked the court for permission to apologize to the survivors. When it was granted, she turned to face them and said-while bowing 90 degrees and sobbing uncontrollably-"I am extremely sorry for what my son has done and for what you have had to go through" (at which point I had to wipe my own eyes). One of the judges cried as this mother spoke, and four of the lay judges also cried during this trial - two of them openly and often. These tears at trial

\footnotetext{
${ }^{37}$ Franklin E. Zimring, The Contradictions of American Capital Punishment (Oxford University Press, 2003), pp. 42-66.
} 
express a wide range of emotions, from sadness, sorrow, and regret to anguish, anger, and rage. ${ }^{38}$

While emotions are a fact of life, it is difficult to discern their proper role in a criminal trial. In 1977 the U.S. Supreme Court held that "it is of vital importance to the defendant and to the community that any decision to impose the death sentence be, and appear to be, based on reason" (Gardner v. Florida). More broadly, one theme of American jurisprudence since the 1970s has been the effort to "rationalize" the sentencing process, which requires the substitution of rational principles and rule-of-law values for punitive passions and unguided jury discretion. But ironically, the U.S. Supreme Court also permits prosecutors to present "victim impact" evidence in the penalty phase of capital trials (though in America victims are not allowed to make specific sentencing requests such as "I demand a death sentence"). It is hard to imagine a rule that is more contrary to the Court's rationalizing reforms. ${ }^{39}$

In Japan, the victim participation system permits the family and friends of homicide victims to lobby for death penalty outcomes, which they frequently do. But allowing the bereaved to beg for a capital sentence can distort the court's deliberations and the prosecutors' decision about whether to seek a death sentence in the first place. In one murder trial, a parade of two surviving parents, their attorney, four victims, and two prosecutors spent more than three hours of the final trial session begging for the defendant to be given the death sentence that he eventually received. In another, the sister of a murder victim started her testimony by stating that she "hates" the defendant, and the longer she spoke the more passionate she became. She sobbed while reading her statement, and she emphasized how "vexed" she felt by the defendant's "evil acts." She even rebuked the defendant for trying to "trick" the court in his testimony. "You merely said what was convenient for you," she insisted. "Give us the lives of our loved ones back!" Near the end of her statement she broke into gasping sobs and, when she could not continue, someone stepped forward to finish reading it to the lay judge panel. The final words were as follows:

${ }^{38}$ David T. Johnson, “Capital Punishment Without Capital Trials in Japan's Lay Judge System”, The Asia-Pacific Journal/Japan Focus, Vol. 7 (2009), p. 7.

${ }^{39}$ David Garland, Peculiar Institution: America's Death Penalty in an Age of Abolition (The Belknap Press of Harvard University Press, 2010), p. 279. 
I went to visit my sister's grave the other day, and I told her that the next time I come I will definitely bring news of a death sentence. My beloved sister is watching this trial, and I really want the court to give us a death sentence. I desire a death sentence. I hope you will do as I request. ${ }^{40}$

Japanese officials often justify capital punishment in terms of retribution, but retribution can be the victim's vengeance in disguise. Moreover, proponents of capital punishment often hide behind victims by identifying with their wrath, because this is a more comfortable expression of their own feelings than a direct statement would be. This kind of hiding is especially common among prosecutors, who claim they want to serve survivors when the latter's preferences align with their own, but who ignore survivors' preferences when they point in a different (non-capital) direction. Some prosecutors also fail to serve the bereaved by neglecting to inform them that a capital sentence will probably result in prolonged litigation before an execution can occur. A sense of an ending is unlikely to come for years or even decades. In some respects this is how it should be, for in the administration of capital punishment, the quick is the enemy of the careful.

Decisions about the death penalty are too important to be made by or for survivors. In a democracy, no minority, even those whose tragedies burn our hearts, should be empowered to speak for everyone. ${ }^{41}$ It is difficult to discern the proper role for citizens' preferences in structuring the governance of punishment in democratic systems. The preferences of victims and survivors may be relevant, but they must not be allowed to marginalize other practical and jurisprudential considerations. Too often, though, the feelings of survivors are presented as trump cards that should take precedence over everything else.

At present, the hunger of victims for revenge remains one of the least discussed but most pervasive forces in Japanese capital punishment. Because Japanese law does not recognize that death is different, it provides little protection against the powerful push of survivors' anger and anguish. And because of the central role that emotions play in Japanese murder trials, it is imperative to create a two-stage system of trial that

${ }^{40}$ David T. Johnson, “Capital Punishment Without Capital Trials in Japan's Lay Judge System”, The Asia-Pacific Journal/Japan Focus, Vol. 7 (2009), p. 6.

${ }^{41}$ Scott Turow, Ultimate Punishment: A Lawyer's Reflections on Dealing with the Death Penalty (Farrar, Straus and Giroux, 2003), p. 56. 
separates guilt-determination from sentence-determination. This is especially urgent when a defendant pleads not guilty, for research shows that the probability of a criminal conviction increases when judges and jurors hear victim testimony ("The defendant must atone with his life!") that is unrelated to the question of guilt. ${ }^{42}$

The death penalty is often an act of revenge, and vengeance is not a principled justification for the ultimate punishment; it is a violent emotion that insists on its own righteousness. It is, therefore, dangerousnot least to the person who feeds it. As sages have cautioned for centuries, "Before you embark on a journey of revenge, dig two graves."

\section{Entrenchment or Change?}

The number of countries to abolish capital punishment has increased remarkably in recent years. One cause of this surge in abolition is the emergence of a "human rights dynamic" that recognizes capital punishment as a denial of the universal human rights to life and to freedom from cruel and inhuman punishment. ${ }^{43}$ The fate of capital punishment in countries that retain it will be shaped by the ongoing battle between two competing frames. Is the death penalty a matter of human rights? Or is it a victim service program?

During the last decade, victims have acquired more influence in Japanese murder trials and in the pretrial and appellate processes. The result is that Japanese capital punishment is shaped by a culture of vengeance. In this culture, vengeance is both an individual victim's emotional reaction to loss and a form of public anger. In both forms, vengeance insists on its own righteousness-no matter what. ${ }^{44}$ Because of this self-righteous certainty, vengeance has little regard for factual or moral complexity. Vengeance also promises a catharsis that cannot come through capital punishment (only the attachments that people have to each other can provide some sense of relief). And vengeance is undemocratic when it privileges the emotions of a handful

\footnotetext{
${ }^{42}$ Itoh Yuji, Saibanin no Handan no Shinri: Shinrigaku Jikken kara Semaru (Keio Gijuku Mitatetsu Gakkai, 2019), pp. 48-66.

${ }^{43}$ Roger Hood and Carolyn Hoyle, "Abolishing the Death Penalty Worldwide: The Impact of a "New Dynamic", Crime and Justice, Vol. 38, No. 1 (2009), pp. 1-63.

${ }^{44}$ Terry K. Aladjem, The Culture of Vengeance and the Fate of American Justice (Cambridge University Press, 2008).
} 
of people. In thinking about capital punishment in the Japanese future, the tradeoff is not between "concern for victims" and some misplaced "compassion for offenders" (as many observers suppose). It is between vengeance and human rights.

Japan's culture of vengeance can be resisted. One recourse is a more skeptical awareness of the disutility of anger in deciding criminal punishments. Another is a willingness to buck the tides of popular sentimentan openness to doubting what others see as moral and factual certainties. But above all, challenging Japan's culture of vengeance requires recognizing that vengeance is a kind of "wild justice": the more people run to it, the more law ought to weed it out. ${ }^{45}$ All of these forms of resistance presuppose personal and political courage. They will not be easy. But as Aristotle observed, courage is the first of human virtues because it makes all of the others possible. Without the courage that enables resistance to Japan's culture of vengeance, the victim participation system could entrench capital punishment more deeply into Japanese law and society.

As for Japan's lay judge reform, the future effects of this form of citizen participation are difficult to discern. On the one hand, it is widely considered imperative not to "burden" (futan) lay judges unduly. Indeed, Japanese judges, journalists, and citizens are so concerned about the physical and emotional "burdens" purportedly imposed on lay judges that this secondary objective threatens to displace core aims of criminal justice, such as fairness, justice, and accuracy. The preoccupation with the well-being of lay judges can be seen in newspaper headlines such as these: Extreme Burden for Lay Judges (Nikkei); The Psychological Fatigue of Lay Judges (Mainichi); Lay Judge Duty Takes a Heavy Toll (Yomiuri); and An Appeal to Care for the Hearts of Lay Judges (Asabi). The central premise of any system of capital justice is that the ultimate punishment must be administered in a manner that is fair, just, and accurate. This is partly a question of factual accuracy-whether the defendant actually committed the crime for which he or she has been charged. But even if a system of justice were able to eliminate the possibility of sentencing an innocent person to death (and this is not possible, as explained in Chapter 4), another crucial question concerns the moral accuracy of death penalty decisions. Capital punishment ought to be administered in a manner that is both

${ }^{45}$ Susan Jacoby, Wild Justice: The Evolution of Revenge (Harper \& Row, 1983). 
consistent (treating like cases alike) and individualized (treating different cases differently). And capital punishment must also be administered based on a careful consideration of each defendant's culpability, not on morally irrelevant factors such as class, the intensity of a victim's anger, or judicial and public convenience. In Japan, factual and moral accuracy are being threatened by a jurisprudence which assumes that death is not different, and by the reluctance of judges to deviate from a pre-established trial script that has been designed to minimize the "burdens" imposed on lay judges. An excessive concern with the emotional well-being of lay judges creates perverse incentives because it encourages judges to cut corners in the criminal process in order to protect the valuable time and vulnerable psyches of their lay colleagues on the bench-and in order to protect themselves from criticism, too. One analyst believes the end result of this misplaced focus will be a "dead culture of law" in which core criminal justice values are subordinated to the tertiary concerns of convenience and efficiency. ${ }^{46}$ More broadly, the presence of lay judges in Japan conveys the impression that the public is making lifeand-death decisions when in fact state officials-prosecutors and judges especially - are still the voices that matter most. The perception that "the people" are doing it may bolster the legitimacy of capital punishment and make it more resistant to reform and repeal.

On the other hand, the full effects of legal reform will take many years to realize ${ }^{47}$ If the lay judge reform is "a stone into the pond" of Japan's criminal process, its' ripples could slowly transform capital punishment by insisting that state killing is not just state business - it is the business of civil society too. The fresh eyes of society are important because, in law as in life, the more one looks at a thing, the less one sees it. As the English writer G. K. Chesterton observed a century ago:

It is a terrible business to mark a man out for the vengeance of men. But it is a thing to which a man can grow accustomed, as he can to other terrible things...The horrible thing about all legal officials—even the best—about

${ }^{46}$ Takano Takashi, "Saibanin Seido no Koka: 10nen o Furikaette", Jiyu to Seigi, Vol. 70, No. 5 (May 2019), pp. 26-29.

${ }^{47}$ David T. Johnson and Setsuo Miyazawa, "Japanese Court Reform on Trial”, in Rosann Greenspan, Hadar Aviram, and Jonathan Simon, editors, The Legal Process and the Promise of Justice: Studies Inspired by the Work of Malcolm Feeley (Cambridge University Press, 2019), pp. 122-138. 
all judges, magistrates, barristers, detectives, and policemen, is not that they are wicked (some of them are good), and not that they are stupid (several of them are quite intelligent). It is simply that they have got used to it. Strictly, they do not see the prisoner in the dock; all they see is the usual man in the usual place. They do not see the awful court of judgment; they only see their own workshop. ${ }^{48}$

Many Japanese judges have "got used to" presuming that "the usual man in the usual place" deserves (more or less) the punishment that prosecutors propose. ${ }^{49} \mathrm{~A}$ conviction rate close to 100 percent testifies to this terrible tendency, and so does a Mainichi newspaper survey (March 9, 2011) which found that not a single prosecutor (out of 40) believed Japan's high conviction rate reflects problems in the judiciary. Defense lawyers have also grown "used to" being passive in the criminal process. Many seem not to appreciate how terrible "the awful court of judgment" can be for the person being judged. For criminal defendants, the right to an attorney is the most fundamental right because it is the one that makes all other rights meaningful. If defense lawyers fail to seize the opportunities afforded by the lay judge reform, it will likely end in disappointment. Rights are rarely bequeathed by benevolent authorities; they emerge out of experience with injustice, and getting them recognized requires that defense lawyers raise a little hell. If the ripples of the lay judge reform do continue to spread, then the common sense of citizens could help correct the tendency of judges to see "the awful court of judgment" as their own familiar workshop-and defense lawyers may realize they are no longer "talking to a wall." This, anyway, is a scenario for the future that recognizes potential for change in Japanese capital punishment through the mechanism of citizen participation. Time will tell more. The final chapter of this book explores how public opinion and politics could shape Japanese capital punishment in the years to come.

${ }^{48}$ G. K. Chesterton, “The Twelve Men," in Tremendous Trifles (1909).

${ }^{49}$ Segi Hiroshi, Zetsubo no Saibansho (Kodansha Gendai Shinsho, 2014). 
Open Access This chapter is licensed under the terms of the Creative Commons Attribution-NonCommercial-NoDerivatives 4.0 International License (http://creativecommons.org/licenses/by-nc-nd/4.0/), which permits any noncommercial use, sharing, distribution and reproduction in any medium or format, as long as you give appropriate credit to the original author(s) and the source, provide a link to the Creative Commons license and indicate if you modified the licensed material. You do not have permission under this license to share adapted material derived from this chapter or parts of it.

The images or other third party material in this chapter are included in the chapter's Creative Commons license, unless indicated otherwise in a credit line to the material. If material is not included in the chapter's Creative Commons license and your intended use is not permitted by statutory regulation or exceeds the permitted use, you will need to obtain permission directly from the copyright holder.

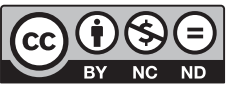

